\title{
Humanisme Pendidikan Islam Perspektif Bediuzzaman Said Nursi
}

\author{
Kharis Ma'ruf \\ UIN Sunan Kalijaga Yogyakarta \\ kharismaruf@gmail.com
}

\begin{abstract}
Islamic education humanism has an important position to form a complete personal figure. This study will describe the Bediuzzaman Said Nursi's thought related to Islam and humanism. This research is qualitative research, with the object of research on library materials with a comprehensive approach, interpretation and inductive approach in drawing conclusions. The results of the study show Said Nursi in the practice of Islamic education has the character of religious humanism thinking, which is a religious concept that places humans as human beings in accordance with the purpose of creation by the Creator, as well as the teaching efforts of the sciences with a foundation that remains in the faith, understanding the Koran, and synergy scientific. This concept is an effort to unite religious values with humanity. Thus, the humanism of Islamic education in the perspective of Bediuzzaman Said Nursi, is a concept that is able to develop human potential both worldly and ukhrowi aspects so as to be able to create balanced human beings in relation to fellow beings (hablun minannas) and with the Creator (hablun) minallah).
\end{abstract}

Abstrak: Humanisme pendidikan Islam memiliki posisi penting untuk membentuk sosok pribadi yang lengkap. Oleh karena itu, penelitian ini akan mendeskripsikan pemikiran Bediuzzaman Said Nursi yang terkait dengan Islam dan humanism. Penelitian ini adalah penelitian kualitatif, dengan objek penelitian bahan pustaka dengan pendekatan komprehensif, interpretasi dan pendekatan induktif dalam menarik kesimpulan. Hasil penelitian menunjukkan Said Nursi dalam praktik pendidikan Islam memiliki karakter pemikiran humanisme religius, yang merupakan konsep 
keagamaan yang menempatkan manusia sebagai manusia sesuai dengan tujuan penciptaan oleh Sang Pencipta, serta upaya pengajaran ilmu-ilmu dengan landasan yang tetap pada iman, pemahaman Alquran, dan sinergi ilmiah. Konsep ini merupakan upaya menyatukan nilai agama dengan kemanusiaan. Dengan demikian, humanisme pendidikan Islam dalam perspektif Bediuzzaman Said Nursi, adalah konsep yang mampu mengembangkan potensi manusia baik aspek duniawi maupun ukhrowi sehingga mampu menciptakan manusia yang seimbang dalam hubungannya dengan sesama makhluk (hablun minannas) dan dengan Sang Pencipta (hablun) minallah).

Kata kunci: Islamic Education, Humanism, Bediuzzaman Said Nursi

\section{A. Pendahuluan}

Humanisme berasal dari kata latin humanis dan mempunyai akar kata "homo" yang berarti manusia. Humanis berarti 'bersifat manusiawi' sesuai dengan kodratnya. Semula humanisme merupakan sebuah gerakan yang mempromosikan harkat, martabat, dan nilai-nilai kemanusiaan. Sebagai aliran pemikiran kritis yang berasal dari gerakan yang menjunjung tinggi manusia, humanisme menekankan harkat, peranan, dan tanggung jawab manusia. ${ }^{1}$

Freire dengan menggunakan pendekatan humanis membangun konsep pendidikannya melalui manusia sebagai subjek aktif. Manusia diajak untuk terus menerus memanusiakan diri mereka lewat menamakan (naming) dunia dalam aksi refleksi manusia dengan manusia lain. Bagi Freire manusia adalah makhluk praksis yang hidup secara otentik hanya ketika terlibat dalam transformasi dunia. Teori pendidikannya didasarkan pada keyakinan yang tinggi terhadap manusia, Freire menolak bahwa manusia itu bagaikan bejana kosong. Baginya setiap individu mempunyai pengetahuan dan pendapat yang bernilai.

Terdapat tujuh hal penting dalam humanime menurut Ali Syari'ati, yaitu: 1) Manusia adalah makhluk asli; 2) Manusia adalah makhluk yang memiliki kehendak bebas, dan ini merupakan kekuatan paling besar luar biasa; 3) Manusia adalah makhluk sadar (berfikir), dan ini merupakan karakteristik menonjolnya; 4) Manusia adalah 1997), h.93.

${ }^{1}$ A. Mangunhadjana, Isme-Isme Dari A Sampai Z (Yogyakarta: Kanisius, 
makhluk sadar akan dirinya; 5) Manusia adalah makhluk kreatif; 6) Manusia adalah makhluk yang punya cita-cita dan merindukan sesuatu yang ideal; 7) Manusia adalah makhluk yang bermoral. ${ }^{2}$

Guru yang humanis harus tepat dalam memahami hubungan antara kesadaran manusia dan dunia. Bentuk pendidikan yang membebaskan dalam definisi ini menawarkan suatu arkeologi kesadaran. Dengan usahanya sendiri, orang bisa menghidupkan kembali proses alamiah dimana kesadaran timbul dari kemampuan mempersepsi diri.

Pemikiran-pemikiran kritis sangat diperlukan agar proses pendidikan yang humanis dapat terlaksana dengan baik. Proses menumbuh kembangkan kesadaran kritis dapat dilakukan melalui edukasi dan pedagogi yang bertumpu pada tiga tahapan, yaitu: 1) Naming, mempertanyakan sesuatu: What is the problem? 2) Reflecting, proses mencari akar masalah dengan pertanyaan: Why is the happening? 3) Acting, proses mencari alternatif pemecahan masalah: What can be done to change the situation?

Tiga tahapan di atas merupakan derivasi dari filsafat praksis yang menghubungkan antara teori dan praktek, refleksi dan aksi. ${ }^{3}$ Dengan demikian pendidikan humanis memandang bahwa peserta didik adalah manusia yang mempunyai potensi dan karakteristik yang berbeda-beda. Karena itu, dalam pandangan ini peserta didik ditempatkan sebagai subjek sekaligus objek pembelajaran. Sementara guru diposisikan sebagai fasilitator dan mitra dialog peserta didik. Materi pembelajaran yang disusun berdasarkan kebutuhan dasar peserta didik, bersifat fleksibel, dinamis dan fenomenologis, sehingga materi tersebut bersifat kontekstual dan memiliki relevansi dengan tuntutan dan perubahan sosial. Model materi pembelajaran tersebut mendorong terciptanya kelas pembelajaran yang hidup (life classroom). ${ }^{4}$

Sebagai pembahasan pokok dalam penelitian ini adalah bagaimana pemikiran Bediuzzaman Said Nursi yang terkait dengan Islam dan humanism? dengan objek penelitian adalah bahan pustaka dari beberapa karya Bediuzzaman Said Nursi, baik dalam bentuk buku

2 Ali Syari'ati, Humanisme Antara Islam Dan Mazhab Barat (Bandung: Pustaka Hidayah, 1996), h.48-48.

${ }^{3}$ M. Agus Nuryatno, "Isu-Isu Kritis Dalam Pendidikan Islam (Perspektif Pedagogik Kritis)," Jurnal Pasca Sarjana UIN Sunan Kalijaga Volume 9, Nomor 2 (2010): h.206.

${ }^{4}$ Dede Rosyada and dkk, Pendidikan Kewarganegaraan (Civil Education) (Jakarta: Prenada Media, 2003), h.12. 
maupun dokumen lainnya yang berkaitan dengan konsep humanisme pemikiran pendidikan Islam Bediuzzaman Said Nursi. Untuk medukung jalannya penelitian ini peneliti menggunakan pendekatan komprehensif, interpretasi dan pendekatan induktif dalam menarik kesimpulan.

\section{B. Sejarah Humanisme}

Arti istilah humanisme akan lebih mudah dipahami kalau kita meninjaunya dari dua sisi; sisi historis dan sisi aliran-aliran dalam filsafat. Dari sisi pertama, humanisme merupakan gerakan intelektual dan kesusastraan yang pertama kali muncul di Italia pada paruh abad ke-14 Masehi. Gerakan ini boleh dikatakan sebagai motor penggerak kebudayaan modern, khususnya kebudayaan eropa, beberapa tokoh yang sering disebut sebagai pelopor gerakan ini misalnya Dante, Petrarca, Boccaceu dan Michael Angelo. Dari sisi yang kedua humanisme sering diartikan sebagaimana telah disebutkan di atas sebagai faham dalam filsafat yang menjunjung tinggi nilai dan martabat manusia, sehingga manusia menempati posisi yang sangat penting dan sentral, baik dalam perenungan filsafat maupun praktisi dalam kehidupan sehari-hari, salah satu asumsi yang melandasi pandangan filsafat ini adalah manusia pada prinsipnya merupakan pusat dari realitas, berbeda dengan filsuf abad pertengahan, para filsuf humanisme berpegang teguh bahwa manusia pada hakikatnya adalah bukan Viator Mundi (peziarah di muka bumi) melainkan Vaber Mundi (pekerja atau mencipta dunia). ${ }^{5}$ Gerakan yang berawal dari Italia dan kemudian menyebar ke seluruh Eropa, dimaksudkan untuk membangunkan manusia dari tidur panjang abad pertengahan, yang dikuasai dogma-dogma agamis. Abad pertengahan adalah abad dimana otonomi, kreativitas dan kemerdekaan berfikir manusia dikungkung oleh kekuasaan agama yang mayoritas di Eropa pada saat itu. Abad ini sering disebut "abad kegelapan" karena cahaya akal budi manusia tertutup kabut dogma-dogma agama di sana.

Kuasa manusia dipatahkan oleh pandangan agama yang menyatakan bahwa hidup manusia telah digariskan oleh kekuatan Illahi dan akal budi manusia tidak akan pernah sampai pada misteri dari kekuatan-kekuatan itu. Pikiran-pikiran manusia yang menyimpang dari dogma-dogma kaum spiritual di Eropa tersebut adalah pikiran-pikiran sesat dan karenanya harus dicegah dan dikendalikan. Dalam zaman itulah gerakan humanisme muncul dan gerakan kaum humanis bertujuan untuk melepaskan diri dari belenggu kekuasaan lembaga keagamaan dan membebaskan kungkungan agama yang mengikat.

\footnotetext{
${ }^{5}$ Baedhowi, Humanisme Islam (Yogyakarta: Pustaka Pelajar, 2008), h.17.
} 
Kaum humanis menggunakan seni liberal sebagai materi dan sarana utamanya. Alasan utama dijadikan sarana terpenting pada waktu itu (disamping retorika, sejarah, etika dan politik) adalah kenyataan bahwa hanya dengan seni liberal manusia akan tergugah untuk menjadi manusia, menjadi makhluk bebas yang tidak terkungkung kekuatan diluar dirinya.

Mereka percaya bahwa hanya dengan seni liberal, manusia akan dapat dibangunkan dari tidurnya yang sangat panjang pada abad pertengahan itu. Model pendidikan itu adalah model pendidikan yang didorong oleh semangat zaman antik (Yunani Kuno), yang ditandai oleh adanya kehidupan demokratis, pada zaman antik klaim atas otonomi manusia dijunjung tinggi dan dalam batas-batas tertentu manusia mempunyai kewenangan sendiri dalam dalam keterlibatannya dengan alam dan dalam penentuan arah sejarah manusia. ${ }^{6}$ Hal senada juga dikatakan oleh Ali Syari'ati bahwasanya teori humanisme barat dibangun atas asas yang dibangun mitologi Yunani Kuno yang memandang bahwa antara langit dan bumi, alam dewa-dewa dan alam manusia, terdapat pertentangan dan pertarungan, sampai-sampai muncul kebencian dan kedengkian antara keduanya. Para dewa adalah kekuatan yang memusuhi manusia. Seluruh perbuatan dan kesadarannya, serta kekuasaannya yang zalim terhadap manusia yang dibelenggu kelemahan dan kebodohannya. Hal itu dilakukan karena dewa-dewa takut menghadapi ancaman kesadaran, kebebasan, kemerdekaan dan kepemimpinan manusia atas alam. ${ }^{7}$

Setiap manusia yang menempuh jalan ini dipandang telah melakukan dosa besar dan memberontak kepada dewa-dewa. Dewadewa dalam mitologi Yunani adalah penguasa segala sesuatu dan manifestasi dari kekuatan fisik yang terdapat di alam semesta: laut, sungai, bumi, hujan, ekonomi, penyakit, dan kematian. Itu sebabnya maka menjadi wajar dan logislah bila dalam pandangan Yunani Kuno yang memitoskan alam tersebut, humanisme mengambil bentuk sebagai penentang kekuasaan para dewa, yakni tuhan-tuhan dan sesembahan mereka. Dari sini terbentuklah pertarungan antara humanisme dan theisme (kepercayaan dengan adanya Tuhan). Berdasar itu maka humanisme Yunani berusaha untuk mencapai jati diri manusia dengan seluruh kebenciannya kepada Tuhan dan pengingkarannya atas kekuasaanNya. Serta memutuskan tali penghambaan manusia dengan langit, ketika ia menjadikan manusia sebagai penentu benar atau tidaknya sesuatu perbuatan dan menentukan segala potensi keindahan terletak pada tubuh manusia.

${ }^{6}$ Achmadi, Ideologi Pendidikan Islam (Yogyakarta: Pustaka Pelajar, 2008), h.4.

${ }^{7}$ Ali Syari'ati, Humanisme Antara Islam Dan Mazhab Barat, H.25.

Analisis: Jurnal Studi Keislaman, Volume 17, No. 2 Tahun 2017 
Kalau kita bisa mengatakan humanisme pasca Renaisance di Eropa modern merupakan kelanjutan dari humanisme Yunani Kuno, karena kungkungan dogma agama mayoritas di Eropa yang demikian kuatnya terhadap nilai kemanusiaan, maka humanisme Eropa modern mengambil bentuk yang sama terhadap humanisme Yunani Kuno yaitu melakukan pengagungan kembali terhadap harkat dan martabat pada nilai kemanusiaan.

\section{Humanisme Perspektif Islam}

Islam mempunyai pandangan yang unik dan komprehensif tentang kemanusiaan (humanisme). Pandangan Islam mengenai nilainilai kemanusiaan diawali dengan semangat pembebasan melalui konsep tauhid, yaitu pembebasan manusia dari segala sesuatu selain kepada Allah. Menurut Nurcholis Majid, Islam mempunyai konsep dan efek konsep dari pembebasan tauhid. ${ }^{8}$

1. Egalitarianisme dalam Islam

Efek konsep mengenai pembebasan manusia pada pemeluknya (tauhid) terbukti pada pemeluknya Afrika Hitam terhadap penindasan bangsa kulit putih, dampak pembebasan yang paling penting adalah dengan terjadinya egalitarianisme (sederajat). Salah satu rangkaian tauhid atau Ketuhanan Yang Maha Esa ialah paham tertentu tentang hakikat dan martabat manusia. Dapat ditegaskan bahwa tidak ada tauhid tanpa menghasilkan pandangan tertentu tentang harkat dan martabat manusia.

2. Konsep Pembebasan Manusia dalam Islam

Konsep pembebasan manusia tauhid ini merupakan turunan dari kalimah tauhid yaitu: "Tiada Tuhan selain Allah" yang merupakan kalimat negasi-afirmasi. Dengan negasi itu dimulai proses pembebasan, yaitu pembebasan dari belenggu kepercayaan kepada hal yang palsu. Tetapi demi kesempurnaan kebebasan itu, manusia harus mempunyai kebebasan yang benar. Sebab hidup tanpa kepercayaan sama sekali itu, adalah hal yang mustahil. Sebagaimana ditunjukkan eksperimen komunisme yang telah disinggung di atas, seseorang dapat memulai dengan tidak percaya sama sekali, namun kekosongan dari kepercayaan itu memberi tempat bagi timbulnya kepercayaan baru yang justru lebih mencekam dan lebih membelenggu. Ini sejajar dengan ucapan bijak bung Hatta bahwa kebebasan yang tidak terbatas

${ }^{8}$ Nurcholis Majid, Islam Doktrin Dan Peradaban; Sebuah Telaah Kritis Tentang Masalah Keimanan, Kemanusiaan Dan Kemoderenan (Jakarta: Yayasan Wakaf Paramadina, 1995), H.85. 
atau bertanggung jawab akan justru mengundang lawan kebebasan itu sendiri yaitu tirani, atau dengan ungkapan lain, kebebasan terwujud dengan ketundukan tertentu, yaitu ketundukan secara intrinsik (harkat) benar, yakni benar pada dirinya sendiri, tidak pada faktor luar secara tidak sejati. Islam yang berarti pasrah atau tunduk menurut Smith justru merupakan pangkal kebebasan kaum muslimin dan sumber energi mereka yang hebat, sebagaimana terbukti ledakan politik orang-orang Arab muslim abad ke-7.

3. Konsep Islam tentang Manusia sebagai Pemimpin di Muka Bumi

Dalam Islam sebagaimana agama monoteis (penganut ajaran yang mempercayai dengan adanya satu Tuhan) lainnya, manusia tampak sebagai makhluk yang mempunyai keistimewaan kerena dipilih Tuhan sebagai wakil-Nya di dunia. Manusia itu adalah tanda ajaib dari kekuasaan Tuhan. Manusia sempurna di alam kecil (micro cosme) yang menyinarkan kesempurnaan alam besar (macro cosme) dan dengan begitu berhak untuk menjadi khalifah Tuhan di atas bumi. Adanya manusia sebagai bukti adanya Tuhan memberikan kedudukan yang tinggi kepada manusia itu sendiri.

4. Kebebasan (ikhtiar), keharusan universal (takdir) dan tanggung jawab.

Kebebasan dalam Islam digambarkan Islam dalam terminologi ikhtiar. Pusat kemanusiaan terletak pada diri pribadi manusia dan kebebasan pribadi adalah hak asasinya yang pertama. Tidak ada sesuatu yang lebih berharga daripada kemerdekaannya itu. Kebebasan dalam arti kerja sukarela (pilihan) yang tanpa paksaan yang didorong kemauan yang murni, kebebasan dalam pengertian merdeka memilih, sehingga pekerjaan itu dengan benar-benar dilakukan sejalan dengan hati nurani. Hal ini bersumber dari keihklasan. Keikhlasan merupakan pernyataan kreatif kehidupan manusia yang berasal dari perkembangan tidak terkekang dari kemauan baiknya. Keikhlasan adalah gambaran terpenting dari gambaran manusia sejati. Individualitas adalah pernyataan asasi yang pertama dan terakhir dari kemanusiaan, serta letak kebenarannya dari nilai kemanusiaan itu sendiri. Karena individu adalah penanggung jawab terakhir dan mutlak dari awal perbuatannya, maka kemerdekaan/ kebebasan pribadi adalah haknya yang pertama dan asasi. Tetapi individualitas hanyalah pernyataan asasi dan primer saja dari kemanusiaan. Kenyataan lain sekalipun sekunder, ialah bahwa 
individu dalam suatu hubungan tertentu dengan dunia sekitarnya adalah kenyataan. Batas-batas tertentu itu karena adanya hukumhukum yang pasti dan tetap menguasai alam dan tidak tunduk ataupun bergantung pada manusia. ${ }^{9}$

Pemuliaan manusia sebagai pemimpin (the ruler, leader) di muka bumi dalam Islam, sebagai pemimpin di muka bumi manusia dalam pandangan Islam, manusia diberikan ilmu pengetahuan dan dengan itu manusia dapat berfikir dan bertindak bebas tetapi segala sesuatu harus dipertanggungjawabkan di akhirat (eskatologis) konsep yang sebenarnya adalah untuk menghormati diri si mukmin itu sendiri, dan orang lain di sekitarnya dan menjadi makna dari pembebasan individu kepada pembebasan sosial. Hal ini diungkapkan Prof. Marcell A. Boisard; wahyu Qur'an dimaksudkan untuk memperbaiki kemanusiaan atas dasar "seorang manusia yang terbaik". ${ }^{10}$ Pengetahuan yang diberikan Tuhan Yang Maha Kuasa, hukum yang dilakukan dan ancaman sanksi yang diumumkan, semua itu hanya berakibat meninggikan derajat seorang mukmin. Takut kepada Tuhan adalah suatu hal yang berlainan dan yang lebih tinggi dari kegelisahan. Takwa menunjukkan dan menjelaskan keagungan rasa tanggung jawab yang dibawa oleh manusia. Kekejaman neraka dalam rangka ini, harus dihubungkan dengan kebesaran manusia yang bertanggungjawab dan diberi akal pikiran. Dengan begitu Islam menggabungkan dua konsepsi yang selalu menjadi bahan pertentangan antara filosof-filosof yaitu faham manusia itu berdiri sendiri dalam kebesaran jiwanya dan faham bahwa manusia itu pada dasarnya sangat lemah. Dengan menerima secara sukarela untuk menundukkan diri kepada perintah dan hukum Tuhan. Kejahatan pada pokoknya adalah pembangkangan kepada hukum Tuhan. Manusia kehilangan keseimbangan karena ia tidak mau berbuat sesuai yang dikehendaki Tuhan dan karena ia menolak sendiri kebesaran yang terpendam dalam dirinya. Kesalahan adalah rasa kurang hormat kepada nilai seorang manusia baik disebutkan di sini bahwa kebesaran manusia dan sikap hormat terhadap orang lain telah dijelaskan oleh ajaran Islam.

9 "Hasil-Hasil Kongres HMI XXVII di Graha Insan Cita" (Depok: Penerbit PB HMI, 2010), h.45.

${ }^{10}$ Marchel A Boisard, Humanisme Dalam Islam (Jakarta: Bulan Bintang, 1980), h.57. 


\section{Humanisme Pendidikan Islam Perspektif Bediuzzaman Said Nursi}

Para ilmuan Muslim menilai sejak abad pertengahan ${ }^{11}$ umat Islam mengalami kelesuan, kebuntuan, kejumudan berpikir, salah satunya disebabkan adanya dikotomi ilmu agama dan ilmu umum. Implikasinya, dalam masyarakat terjadilah pemahaman dan pengamalan bahwa ilmu agama saja yang wajib dipelajari, sementara ilmu (sekuler) lainnya merupakan kewajiban minoritas. ${ }^{12}$ Realitas seperti ini, semakin kelihatan pada abad modern terjadi di negaranegara Islam atau negara-negara yang mayoritas dihuni umat Islam, tidak terkecuali di Indonesia terutama lembaga yang masih menggunakan sitem tradisional (salaf).

Munculnya dikotomi pendidikan adalah dikarenakan timbul kesenjangan tentang sumber ilmu antara ilmu-ilmu agama dan ilmuilmu umum. Para pendukung ilmu-ilmu agama hanya menganggap valid sumber-sumber Illahi dalam bentuk kitab suci dan tradisi kenabian dan menolak sumber-sumber non-skriptual sebagai sumber otoritatif untuk menjelaskan kebenaran. Di pihak lain, para ilmuan sekuler hanya menganggap valid informasi yang diperoleh melalui pengamatan indrawi, karena bagi mereka satu-satunya sumber ilmu adalah pengalaman empiris melalui persepsi indrawi (metode induksi).

Ketertinggalan Islam dalam bidang sains berlarut-larut dalam sejarah dan mampu mengubah pendidikan Islam paradigma dikotomis (memisahkan diri dari ilmu-ilmu sekuler), karena akibat sistem pendidikan sekuler barat yang diperkenankan melalui imperialisme. Sehingga, sampai sekarang umat Islam tidak menemukan format pendidikan Islam ideal. Kondisi semacam ini juga dialami negara Indonesia pasca kolonial Belanda (awal kemerdekaan) yang didorong oleh struktural-politis ditandai dengan berdirinya institusi Departemen

11 Harun Nasution, "Maju Mundurnya Umat Islam dalam Sejarah" menjelaskan garis besarnya sejarah Islam dapat dibagi ke dalam tiga periode diantaranya. Pertama, periode klasik, merupakan zaman kemajuan Islam (650-1250 M). Kedua, periode pertengahan, masa kemunduran Islam (1250-1800 M) dan ketiga, periode modern, yaitu timbulnya ide-ide pembaharuan Islam (1800-sekarang dan seterusnya). Dalam, Harun Nasution, Pembaharuan Dalam Islam; Sejarah Pemikiran Dan Gerakan, (Jakarta: Bulan Bintang, Cet. Ke 14 2003), h.4.

12 Baca: Abdurrahman Mas'ud, Dikotomi Ilmu Agama Dan No Agama; Kajian Sosio Historis Pendidikan Islam (Semarang: Pusat Penelitian IAIN Walisongo, 1999). 
Pendidikan Nasional dan Departemen Agama dan sulit untuk disatupadukan. Hakikat problem di atas mengajak umat Islam untuk melupakan sejarah masa kejayaan sains dalam peradaban Islam yang salah satunya diraih karena pendidikan berparadigma terintegratifensiklopedik dipelopori oleh para ilmuan seperti Al Kindi dalam bukunya Aqsam Al Ulum, Al Farabi dalam Ihsa Al Ulum, dan Ibnu Sina dalam Al Syifa. ${ }^{13}$ Dalam kurikulum proses belajar mengajar menggunakan pemaduan antara ilmu-ilmu agama Islam dan ilmu-ilmu hikmah (ilmu Fisika, Kimia, Matematika, Astronomi, Kedokteran, dan lain-lain). Pemisahan hanya pada jurusan keahlian yaitu ilmu-ilmu naqliah dan ilmu-ilmu Aqliah. Pada jurusan ilmu Naqliah diajarkan tafsir Al Qur'an, Hadist, Fiqih dan Usul Fiqih, Akhlak, Nahwu Sharaf, Balaghah, Bahasa Arab dan kesusastraan. Sedangkan, untuk jurusan/ keahlian ilmu-ilmu Aqliah diajarkan Fisika, Kimia, Matematika, Astronomi, Biologi, Kedokteran, Musik, Mantik.

Pendidikan sebagai tiang peradaban mampu membawa peradaban Islam sebagai sistem nilai, pernah berjaya karena diimbangi dengan kesadaran proses dialektik yang masih menjadi ruh dalam kreasi budaya masyarakat pada saat itu, kecintaan pada asupan hikmah pada waktu itu begitu dipegang teguh, baik oleh ilmuan (ulama) dan penguasa (umara) sehingga berimbas pada kemakmuran warga masyarakat yang tidak sekedar materi namun juga immateri (spiritual). Jika pendidikan Islam era modern ini mampu mengembalikan sistem pendidikan terintegrasi seperti yang telah dilakukan oleh para ilmuan terdahulu (abad keemasan) niscaya akan menemukan model pendidikan ideal, terlebih untuk bangsa Indonesia sebagai bangsa beradab.

Secara historis, proses dinamika lahirnya institusi dan lembaga pendidikan Islam merupakan proses akumulasi antara tuntunan zaman (modernisme) dan ideologi keagamaan (tradisionalisme). Pada periode modern, berbagai upaya untuk merebut kembali masa keemasan peradaban Islam terus dilakukan oleh para cendekiawan muslim kontemporer, yang sadar akan melakukan berbagai inovasi dan pembaharuan dalam berbagai bidang ilmu pengetahuan melalui kajian-

13 Baca: M. Amin Abdullah, "Etika Tauhid Sebagai Dasar Kesatuan Epistemologi Keilmuan Umum Dan Agama; Dari Paradigma Positifistik Sekularistik Ke Arah Teoantroposentrik - Integralistik", Epistemologi Islam \& Umum (Jogjakarta: SUKA Press, 2003), h.5. 
kajian keIslaman dan sains, pada tahun 1970 hingga pertengahan 1990an, yang kerap muncul adalah Syed M. Naquib Al Attas dengan "dewesternisasi ilmu"; kemudian Ismail Raji Al Faruqi berbicara tentang "Islamisasi Ilmu"; selanjutnya, Zainuddin Sardar tentang penciptaan suatu "sains Islam kontemporer". ${ }^{14}$

Pada tahun 1925-1960 fenomena Bediuzzaman Said Nursi menjadi pionir dalam pergerakan keagamaan di abad modern di Turki pada abad XX. Ia dikenal merupakan salah satu pengusung intelektual Islam hidup pada masa pemerintahan Kemal Attatruk (penguasa yang mampu merevolusi dari republik Turki menjadi negara sekuler), dengan kegigihannya beliau selalu melakukan gerakan-gerakan frontal melalui pendidikan dan pengajaran. Dalam hal ini, Said Nursi menelorkan ide dan konsep pendidikan Islam yang mencoba memadukan antara pendidikan agama dan pendidikan sekuler. Dengan mengatakan, "dengan cara ini, pelajar di sekolah modern dapat dilindungi dari kekufuran, dan pelajar di sekolah modern bisa dilindungi dari sikap fanatisme."

Said Nursi terus berusaha untuk merealisasikan diri umat Islam sebagai yang harus dicontoh. Pengamatan dan kesadaran telah mendorong dalam mengatur gerakan ke arah reformasi sistem pendidikan, dengan berpendirian teguh bahwa dalam dunia modern, ilmu-ilmu agama dan ilmu-ilmu sains modern perlu bergerak seiring. Corak pembaharuan Nursi adalah "pendidikan untuk umat", baginya, kebodohanlah yang menjadi salah satu penyebab utama kemunduran sehingga dengan sangat mudah umat Islam dijajah dan hidup dalam kekuasaan bangsa asing di negeri sendiri. Oleh sebab itu, usaha Said Nursi pertama kali ialah menyadarkan umat akan pentingnya pendidikan. Usaha ini diiringi dengan penyadaran akan kesatuan dan kepaduan agama dan sains modern dan diwujudkan dengan cara mengajar di sekolahnya, bernama Madrasah Khurkhur, dan berbagai madrasah di kota-kota kecil lainnya.

Di sinilah posisi Said Nursi muncul sebagai pembaharu yang ingin mengadakan perbaikan untuk "menyelamatkan iman dan Islam". Said Nursi memiliki karakter pemikiran yang memihak kepada

${ }^{14}$ Zainal Abidin Bagir, Bagaimana Mengintegrasikan Ilmu Dan Agama, Dalam Zainal Abidin Bagir, Integrasi Ilmu Dan Agama: Interpretasi Dan Aksi (Bandung: Mizan \&MYIA, 2005), h.24. 
keimanan, pemahaman Al Qur'an, hari akhir dan integralitas keilmuan. Said Nursi adalah sosok pemberani dan gigih memperjuangkan umat Islam di Turki pada masa akhir kerajaan Turki Usmani yang mencetuskan gagasan pembelaan terhadap agama dan kehidupan sosial-kemasyarakatan. Said Nursi merupakan salah satu orang besar yang berani mengahadapi dan menyelamatkan umat manusia dari berbagai peristiwa berdarah dan penyimpangan terhadap fitrah manusia. Said Nursi juga menghalangi manusia agar tidak terjatuh ke dalam atmosfer kehancuran dan kebudayaan mereka. ${ }^{15}$

Said Nursi adalah salah satu tokoh yang mampu bertahan dari berbagai upaya barat "menghancurkan" umat Islam dan akhlak umat. Bahkan sampai muncul Republik Turki, ia tetap konsisten berjuang menentang sekulerisasi di Turki hingga menghasilkan sebuah karya "Risale-i Nur" yakni tulisan setebal 6000 halaman yang memuat pemikiran-pemikiran tentang esensi keimanan dan nilai-nilai akhlak abad ini. Said Nursi menginginkan adanya pembaharuan di Turki pada bidang pendidikan dan moralitas umat, yang waktu itu sudah mulai dirusak oleh Mustafa Kemal Attatruk. Karena itu, Said Nursi tampil dengan model sufi modern yang memadukan antara rasionalitas dan spiritualitas, dalam konteks ini dapat dikatakan sebagai rangkaian proses pendidikan akhlak.

Said Nursi dalam berbagai tekanan tersebut tidak kenal menyerah dengan tantangan dan penderitaan yang dialaminya dari penjara ke penjara, berbagai musuh menghadang. Walaupun otoritas negara yang kuat dan mekanisme pendidikan Islam yang ada di Turki saat itu dipengaruhi oleh sekulerisme yang disosialisasikan oleh Mustafa Kemal Attatruk, tapi Said Nursi tetap melakukan usaha menumbuhsuburkan ajaran Islam dan perbaikan dalam pendidikan Islam, terutama upaya membumikan nilai-nilai akhlak di Turki.

Media Said Nursi dalam berdakwah adalah Risale-i Nur dan mengelola pengajian-pengajian. Sebab bagi Said Nursi meminjam istilah Syafi'i Anwar, penyebaran Risale-i Nur merupakan "realisasi menyuluruh bagi para pemikir dan praktisi pendidikan yang handal yang mampu membentuk manusia yang unggul secara intelektual, kaya

15 Ihsan Kasim Salih, Said Nursi Pemikir Dan Sufi Besar Abad 20; Membebaskan Agama Dari Dogmatisme Dan Sekularisme, h.V. 
dalam amal, serta anggun dalam moral dan kebijakan". ${ }^{16}$ Karenanya, Said Nursi berkeyakinan bahwa penyebaran Risale-i Nur merupakan realisasi menyeluruh bagi umat manusia dalam rangka membentuk kepribadian manusia yang seimbang rasionalitas, spiritualitas dan kaya akan amal.

Sebagai suatu kontribusi bagi pemikiran-pemikiran tentang reformasi pendidikan beragama yang digagas oleh pemikir-pemikir muslim lainnya dari berbagai latar belakang intelektual, aliran, lingkungan tempat mereka hidup, Said Nursi, sebagai seorang "fundamentalis"17 dari lingkungan kehidupan tarekat Naksabandiyah di Turki, juga mempunyai gagasan-gagasannya tentang konsep menyatukan kembali pendidikan Islam dan sekuler, inilah yang membedakan Said Nursi dengan tokoh-tokoh Islam modern lainnya, yakni sebagai tokoh pembaharu Islam modern Said Nursi bersifat humanis religius dalam praktik pendidikan Islam.

Paradigma humanis religius dalam praktik pendidikan Islam disini mempunyai maksud bahwa pendidikan adalah proses pemekaran potensi-potensi bawaan dari manusia sebagai makhluk sosial yang berinteraksi terhadap keadaan lingkungan dan manusia sebagai hamba yang mengabdi kepada Allah yang diberi mandat untuk menjadi rahmatan lil'alamin. Abdurrahman Mas'ud menjelaskan bahwa humanisme religius merupakan sebuah konsep keagamaan yang menempatkan manusia sebagai manusia, serta upaya humanisme ilmuilmu dengan tetap memperhatikan tanggung jawab atas ungkapan hablun minallah dan hablun minan-nas. ${ }^{18}$ Pendidikan humanis religius merupakan upaya untuk menyatukan nilai agama dengan kemanusiaan. Bahwa agama tidak hanya sistem kepercayaan tetapi juga merupakan nilai yang berorientasi pada kemanusiaan. Berbeda dengan humanisme sekuler yang hanya bersifat rasionalisme. Humanisme yang hanya didasarkan pada pemikiran akal tidak akan mampu mewujudkan jati diri manusia yang sesungguhnya. Karena pencarian secara akal ini

${ }^{16}$ Inu Kencana Syafi'i, Logika, Etika, Dan Estetika Islam (Jakarta: Pertja, 1998), h.153-154.

${ }^{17}$ Orang yang berpegang teguh pada ajaran agama, atau berfaham kepanutan teguh pada pokok ajaran kepercayaan. Pius A Partanto, "Kamus Ilmiah Populer" (Surabaya: Arkola, 1994), h.189.

18 Abdurrahman Mas'ud, Menggagas Format Pendidikan Nondikotomik: Humanisme Religius Sebagai Paradigma Pendidikan Islam (Yogyakarta: Gama Media, 2007), h.114. 
bersifat probabilitas dan ada potensi untuk tersesat, maka Tuhan pun membuat petunjuk berupa agama.

Bila melihat dari sisi tujuan pendidikan Islam yang ingin dicapai oleh Said Nursi adalah tauhid sebagai landasan pendidikan, tauhid yang berarti keimanan sebagai pokok pembelajaran yang harus ditanamkan dalam diri peserta didik. Hakikat terbesar di dunia dalam pandangan Said Nursi adalah hakikat iman dan tauhid. Seluruh wujud pemikiran Said Nursi ibarat alat tenun yang merangkai hakikat tauhid.

Sedangkan kurikulum yang diharapkan yakni dapat menolong peserta didik untuk membina iman yang kuat, teguh terhadap ajaran agama, berakhlak mulia dan melengkapinya dengan ilmu yang bermanfaat di dunia dan di akhirat. ${ }^{19}$ Diantara tema terpenting yang menjadi perhatian Said Nursi adalah penjelasannya tentang bagaimana iman diposisikan sebagai pamflet yang tersebar dan menjangkau berbagai dimensi hakikat wujud dan manusia. Nursi menganggap pentingnya iman dalam diri seseorang, karena iman merupakan relasi yang menghubungkan manusia dengan pemiliknya. ${ }^{20}$

Seperti yang Nursi katakan, bahwa di permukaan bumi serta di penjuru langit stempel kekuasaan-Nya terlihat, demikian pula di seluruh alam ini stempel tauhid terlihat dengan sangat jelas. ${ }^{21}$ Dari sini dapat dikatakan bahwa tauhid penting sebagai landasan pendidikan. Tauhid penting dalam proses keimanan seseorang karena untuk dapat mengetahui kekuasaan dan keagungan Allah serta pemahaman semua kreasi dan perbuatan-Nya merupakan stempel khusus milik Tuhan pemelihara semesta alam. Menurutnya, cita-cita terpenting setiap makhluk dan hasilnya yang paling mulia adalah keimanan pada Allah. Derajat kemanusiaan yang paling tinggi adalah pengetahuan tentang Allah. Kebahagiaan yang paling indah dan karunia yang paling mulia bagi jin dan manusia adalah kasih sayang Allah yang terkandung dalam pengetahuan tentang Allah; kesenangan yang paling murni bagi jiwa manusia dan kebahagiaan yang paling fitri bagi hati adalah perasaan sukacita jiwa yang terkandung kasih Allah. Sesungguhnya, semua kebahagiaan yang sejati, kegembiraan yang murni, karunia-karunia

${ }^{19}$ Armai Arief, Pengantar Ilmu Dan Metodologi Pendidikan Islam (Jakarta: Ciputat Press, 2002), h.34.

${ }^{20}$ Badiuzzaman Said Nursi, Dari Koleksi Risalah Nur; Al Kalimat, Jilid 1 (Jakarta: Anatolia, 2011), h.519.

${ }^{21}$ Ibid., h.19. 
yang mulia dan kenikmatan yang nyata tidak diragukan lagi terkandung dalam pengetahuan dan kasih Allah. ${ }^{22}$

Seseorang yang tahu dan mencintai. Tuhan berpotensi atau bahkan bisa benar-benar menerima kebahagiaan, karunia, pencerahan, dan kegaiban-kegaiban yang tiada akhir. Sedangkan seseorang yang tidak benar-benar mengetahui dan mencintai-Nya akan menderita baik secara spiritual maupun material karena kesengsaraan, kepedihan, dan kecemasan yang tiada akhir. Jika seseorang menemukan Pemiliknya dan mengenali Tuhannya, maka dia akan menemukan perlindungan di bawah naungan Rahmat-Nya dan percaya pada kekuasaan-Nya, dan kemudian dunia yang fana itu, baginya akan berubah menjadi tempat istirahat dan kedamaian dan menjadi tempat peralihan menuju akhir. ${ }^{23}$ Begitu juga yang harus di tanamkan pada jiwa peserta didik dalam bentuk keimanannya terhadap Allah.

Keimanan tidak terbatas pada penegasan sesaat atas dasar taqlid (imitasi). Keimanan memiliki tingkat dan tahap perkembangan, seperti dari sebutir benih hingga menjadi pohon yang rindang dan menghasilkan buah. Keimanan mengandung begitu banyak kebenaran yang terkait dengan seribu satu dan asma-asma Allah serta realita yang terkandung dalam alam semesta, sehingga sains, pengetahuan dan kebajikan yang paling sempurna dari manusia adalah keimanan dan pengetahuan tentang Allah yang berasal dari keimanan yang didasarkan pada argumen dan penyelidikan (proses belajar). Orangorang yang mampu mencapai tingkat kepastian keimanan yang berasal dari pengamatan langsung terhadap kebenaran yang menjadi dasar keimanan, maka bisa mempelajari alam semesta ini sebagai al Qur'an. ${ }^{24}$

Nursi juga menginginkan untuk mempelajari al Qur'an, menjadikan al Qur'an sebagai kebenaran mutlak dalam pemahaman terhadap iman, di dalamnya terhimpun berbagai ilmu pengetahuan. Tidak hanya sains dan teknologi yang dijadikan patokan dalam memahami alam semesta. ${ }^{25}$ Sebab al Qur'an sebuah kitab yang n.d., h.290.

${ }^{22}$ Said Nursi, Risalah An Nur; Said Nursi: Pemikir Dan Sufi Besar Abad 20,

${ }^{23}$ Said Nursi, Risalah An Nur; Said Nursi: Pemikir Dan Sufi Besar Abad 20.

${ }^{24}$ Ibid., h.xiv.

${ }^{25}$ Ibid., h. 274. 
memiliki kefasihan sempurna, argumen dan kejelasan yang luar biasa, koherensi yang tegas serta proporsi dan harmoni yang kuat. ${ }^{26}$ Aspeknya begitu terang dan terbebas dari keraguan serta pikiran-pikiran aneh. Fondasinya adalah wahyu Illahi dan kata-kata abadi-Nya, yang tujuannya adalah keabadian kekal dan berisi petunjuk murni. al Qur'an dikelilingi dan didukung dari atas dengan cahaya iman, dari bawah dengan tanda dan bukti, dari kanan dengan ketundukan hati dan nurani, serta dari kiri dengan pengakuan akal dan kemampuan intelektual lainnya. ${ }^{27}$

Dari hal di atas maka dalam konsep Humanisme Pendidikan Islam, Bediuzzaman Said Nursi tidak hanya memandang potensi manusia dan ilmu yang mendukungnya dalam kehidupannya di dunia yakni hubungannya dengan sesama (hablun minannas) namun melihat lebih dalam yakni dari pendidikan yang telah diperoleh dapat mengantarkan kepada keridhaan Allah SWT (hablun minallah). Maka dalam memandang pendidikan Islam yang humanis perlunya kesatuan dan saling bersinergi antara ilmu agama dengan ilmu umum. Begitu pula Tauhid di yang dijadikan landasan pendidikan oleh Said Nursi hakekatnya tidak hanya ranah ukhrowi namun juga duniawi.

\section{E. Kesimpulan}

Hasil penelitian menunjukkan bahwa usaha Said Nursi pertama kali ialah menyadarkan umat akan pentingnya pendidikan, dimana islam merupakan "pendidikan untuk umat". Usaha ini diiringi dengan penyadaran akan kesatuan dan kepaduan agama dan sains modern. Di sinilah posisi Said Nursi muncul sebagai pembaharu yang ingin mengadakan perbaikan untuk "menyelamatkan iman dan Islam". Said Nursi dalam praktik Pendidikan Islam memiliki karakter pemikiran humanisme religius, yang merupakan sebuah konsep keagamaan yang menempatkan manusia sebagai manusia sesuai dengan tujuan penciptaannya oleh Sang Pencipta, serta upaya pengajaran ilmu-ilmu dengan tetap berlandaskan kepada keimanan, pemahaman Al Qur'an, hari akhir dan sinergitas keilmuan. Konsep ini merupakan upaya untuk menyatukan nilai agama dengan kemanusiaan. Bahwa agama tidak hanya sistem kepercayaan tetapi juga merupakan nilai yang

\footnotetext{
${ }^{26}$ Said Nursi, Misteri Al Qur'an (Jakarta: Erlangga, 2010), h.207.

${ }^{27}$ Ibid., h.81.
} 
berorientasi pada kemanusiaan. Sehingga, humanisme pendidikan Islam dalam perspektif Bediuzzaman Said Nursi, merupakan sebuah konsep yang mampu mengembangkan potensi manusia baik aspek duniawi maupun ukhrowi sehingga tercipta pribadi yang seimbang dalam hubungannya dengan sesama makhluk (hablun minannas) maupun dengan Sang Pencipta (hablun minallah). [.]

\section{Daftar Pustaka}

A. Mangunhadjana. Isme-Isme Dari A Sampai Z. Yogyakarta: Kanisius, 1997.

Abdurrahman Mas'ud. Dikotomi Ilmu Agama Dan No Agama; Kajian Sosio Historis Pendidikan Islam. Semarang: Pusat Penelitian IAIN Walisongo, 1999.

Menggagas Format Pendidikan Nondikotomik: Humanisme Religius Sebagai Paradigma Pendidikan Islam. Yogyakarta: Gama Media, 2007.

Achmadi. Ideologi Pendidikan Islam. Yogyakarta: Pustaka Pelajar, 2008.

Ali Syari'ati. Humanisme Antara Islam Dan Mazhab Barat.

Bandung: Pustaka Hidayah, 1996.

Armai Arief. Pengantar Ilmu Dan Metodologi Pendidikan Islam. Jakarta: Ciputat Press, 2002.

Badiuzzaman Said Nursi. Dari Koleksi Risalah Nur; Al Kalimat, Jilid 1. Jakarta: Anatolia, 2011.

Baedhowi. Humanisme Islam. Yogyakarta: Pustaka Pelajar, 2008.

Dede Rosyada, and dkk. Pendidikan Kewarganegaraan (Civil Education). Jakarta: Prenada Media, 2003.

Harun Nasution. Pembaharuan Dalam Islam; Sejarah Pemikiran Dan Gerakan. Vol. Cet. Ke 14. Jakarta: Bulan Bintang, 2003.

“Hasil-Hasil Kongres HMI XXVII Di Graha Insan Cita.” Depok: Penerbit PB HMI, 2010, n.d. 
Ihsan Kasim Salih. Said Nursi Pemikir Dan Sufi Besar Abad 20; Membebaskan Agama Dari Dogmatisme Dan Sekularisme, n.d.

Inu Kencana Syafi'i. Logika, Etika, Dan Estetika Islam. Jakarta: Pertja, 1998.

M. Agus Nuryatno. "Isu-Isu Kritis Dalam Pendidikan Islam (Perspektif Pedagogik Kritis).” Jurnal Pasca Sarjana UIN Sunan Kalijaga Volume 9, no. Nomor 2 (n.d.): Desember 2010.

M. Amin Abdullah. "Etika Tauhid Sebagai Dasar Kesatuan Epistemologi Keilmuan Umum Dan Agama; Dari Paradigma Positifistik - Sekularistik Ke Arah TeoantroposentrikIntegralistik”, Epistemologi Islam \& Umum. Jogjakarta: SUKA Press, 2003.

Marchel A Boisard. Humanisme Dalam Islam. Jakarta: Bulan Bintang, 1980.

Nurcholis Majid. Islam Doktrin Dan Peradaban; Sebuah Telaah Kritis Tentang Masalah Keimanan, Kemanusiaan Dan Kemoderenan. Jakarta: Yayasan Wakaf Paramadina, 1995.

Pius A Partanto. "Kamus Ilmiah Populer.” Surabaya: Arkola, 1994.

Said Nursi, Misteri Al Qur'an. Jakarta: Erlangga, 2010.

Said Nursi. Risalah An Nur; Said Nursi: Pemikir Dan Sufi Besar Abad 20, n.d.

Zainal Abidin Bagir. Bagaimana Mengintegrasikan Ilmu Dan Agama, Dalam Zainal Abidin Bagir, Integrasi Ilmu Dan Agama: Interpretasi Dan Aksi. Bandung: Mizan \&MYIA, 2005. 